\title{
About the universality of a concept
} Is there a financialization of daily life in France?

\author{
Sobre a universalidade de um conceito \\ Existe uma financeirização da vida cotidiana na França?
}

Jeanne Lazarus*

\begin{abstract}
Based on the French case, this article aims to challenge the concept of "financialization of daily life". This notion does not perfectly describe the transformation of money management experienced by French households; compared to other developed countries, their money is kept at a remove from financial markets, particularly as the French retail banking system, built in the 1960 s, is designed to "definancialize" and the French welfare state maintains its protective position. The French economy is nonetheless deeply financialized, with great consequences on job and income instability. Public authorities tackle the problem from this angle, with policies increasingly focused on households' money. Social work is expected not only to be an intermediary between individuals and social legislation, but to aid households in navigating their engagements with commercial entities. This leads us to claim that public intervention is becoming monetized.
\end{abstract}

Keywords: Financialization of daily life. France. Household's economy. Social work. Credit.

Resumo: Tomando como referência o caso francês, este artigo propõe colocar à prova a noção de financeirização da vida cotidiana, expressão que não descreve com perfeição as transformações nas formas de gestão do dinheiro experimentadas pelos lares franceses os quais, comparativamente aos lares de outros países desenvolvidos, mantêm seu dinheiro à distância dos mercados financeiros, da mesma forma como o sistema bancário varejista francês, constituído nos anos 1960, foi projetado para "desfinancializar", e que o estado de bem-estar francês se mantém na posição de protetor. A economia francesa, no entanto, se encontra profundamente financeirizada, o que gera instabilidade no emprego e na renda. Sob esse ângulo, as autoridades públicas abordam o problema adotando políticas cada vez mais focadas no dinheiro doméstico. Espera-se que o serviço social não seja apenas um intermediário entre os indivíduos e os direitos sociais legais, mas que ajude os lares a administrarem seus compromissos com as instituições comerciais. Isso nos leva a afirmar que a intervenção pública tornou-se monetarizada.

Palavras-chave: Financeirização da vida cotidiana. França. Economia doméstica. Serviço social. Crédito.

* PhD in Sociology from École des Hautes Études en Sciences Sociales (EHESS, Paris, France). Tenured CNRS research fellow at the Center for the Sociology of Organizations in SciencesPo, Paris, France < Jeanne.lazarus@sciencespo.fr $>$.

Civitas, Porto Alegre, v. 17 , n. 1, p. 26-42, jan.-abr. 2017

Exceto onde especificado diferentemente, a matéria publicada neste periódico 
The concept of financialization of daily life has met with great success since the publication of Randy Martin's eponymous book (2002). This term covers two relatively distinct components: on one hand is the fact that daily activities have been financialized - which is to say that financial businesses have capitalized on them, as with the implementation of insurance policies on practices that had not been financialized before, or with the financialization of social work through social impact bonds; on the other hand is the fact that household money is invested using financial products and that households and individuals must bear financial risks that had previously been mitigated. It is the latter of these elements that has received the lion's share of attention from researchers. Analyses of credit (Langley, 2008a), savings, health insurance, and retirement products, among others, have demonstrated a "risk shift" (Hacker, 2008): people are expected to protect themselves from financial risks individually in a world that no longer guarantees employment and in which group insurance has fallen out of favor. It is important to note that the financialization of household money has occurred in parallel with elements of career and income source destabilization wrought by the financialization of businesses and its effects on work.

The questions that underlie the interest in the financialization of daily life are thus connected to the way of life it promotes. At stake here is the possibility of the existence of a middle class such as the one that emerged in developed countries in the $20^{\text {th }}$ century. The constitution of middle classes in the $20^{\text {th }}$ century was founded on the possibility of financially planning one's life by participating in the world of production, which enables consumption and the raising of children, and which is also an entryway to civic rights, notably through the payment of taxes, social benefits received, and labor laws. The many forms of the welfare state demonstrate that not all countries developed the same solutions, but that all considered the state had to organize forms of security and continuity for their citizens in one way or another - not on the model of complete income equality but on that of access to inclusive public services such as education, healthcare, and even employment. In North America, the access to consumption available to all social categories led society to perceive itself as a vast middle class, divided into strata but with very similar ways of life - simply put, the richest had larger cars and houses than the poorest, but the difference in the experience of life was relatively slight (Zunz, 1998).

The literature on financialization of daily life and risk shift states that these various elements are now falling apart: stability, equal opportunities, equal place in social life, and the feeling that the collectivity is committed to defending a collective model of society and to pursuing equity. 
One part of the literature on financialization describes the inequalities that it produces: not only is it the source of tremendous income inequality (Godechot, 2016; Atkinson et al., 2011), but others have shown that with equal income, having chosen savings and insurance products well, together with having a good credit score can have very different effects on accumulated wealth (Fourcade and Kieran, 2013). While some researchers adopt a critical position in response to these manufactured inequalities, an entire current support that the promotion of financial literacy takes the central role of financial choices in social life for granted and considers it necessary to transform the behavior of individuals in order for them to understand the risks they bear (Lusardi and Mitchell, 2011).

The term "financialization" is used to designate slightly different processes in what is called the "Global South": it is not so much an issue of transforming already existing products as it is of introducing financial products to the masses. Here, we must distinguish between "bankarization" and financialization (Lazarus and Luzzi, 2015). The simple possession of a bank account does not signal that a process of financialization is at work. Indeed, to point out that households possess financial products it is not enough for us to affirm the occurrence of a financialization of daily life - these products must also possess characteristics of instability that connect them to the turbulence of financial markets. The bankarization of Northern Europe in the 1960s, such as in France (Lazarus, 2012) and Sweden (Husz, 2015), occurred slowly and was built on very simple products that were tightly framed by regulation - in France, for example, the largest banks at that time were public companies. The banks in these countries had long acted to buffer upheavals in the financial sector before gradually opening up to riskier products that offered potentially higher returns with related risks. In countries where the spread of banking services took place later, it appeared in more brutal forms that featured less regulation by the state and sometimes foreign private banks that were not forced to play a social role as they had in richer developed countries.

In the scientific literature, the expression "financialization of daily life" thus covers very diverse situations. It signals the description of a world in which individuals find themselves constrained by the faceless private actor called finance, where their desires are greatly shaped by this same actor, as is their inclusion in society, which, through the term "financial inclusion", is itself increasingly associated with their inclusion in finance. The definition of this expression, however, remains relatively vague: for some, it refers to the presence of money or of a formal financial institution in a space that was 
previously given to community trade; for others, the term is used to designate changes in the modes of financing certain public actions and policies, or to point out the need for households to manage their money by using complex financial products.

This article seeks to examine the usefulness of the notion of financialization of daily life through the particular case of France. We will adopt a broad and qualitative definition of financialization of daily life: the fact that traditional modes of saving and credit have been transformed due to having been pulled closer to the instability of market finance. In the first section, we will show that France is a deeply financialized country in terms of its economy, which has major repercussions on the destabilization of employment and the augmentation of precarity and even poverty of a part of the population; notwithstanding, evidence of the financialization of daily life remains thin. In the second section, however, we will examine how the increased precarity of a growing segment of the population has led to transformations in the way that public authorities conceive social action, shifting from a bureaucratic view of household needs to a monetary one.

\section{The role of finance in French household budgets}

To what extent are household budgets financialized in French society?

France has not eluded the wave of financializing economies that has been described by numerous authors (Krippner, 2011; Zwan Van Der, 2014): the share of financial activities in the entirety of economic activity has increased, as has the share of financial activities in non-financial firms, accompanied by its consequences. Job instability, increased unemployment due to outsourcing, and increased inequality, notably by way of stagnating wages for the least qualified jobs, have affected France as they have other countries.

That said, before declaring that a process of financialization of daily life is at work, we must ask whether household money is affected by the hazards of finance, whether the use of financial products has increased, and also whether the ways of life, the modes of consumption, and the relationships between individuals have been transformed directly or indirectly by the use of tools belonging to the realm of finance. Beyond this, the final stage (if we can call it that) of financialization is no longer simply that tools are financialized but that individuals are as well - that they represent forms of investment and liquidity, that they can be transferred and resold, and that their value is first and almost uniquely measured in monetary terms (certain insurers use tools that demonstrate this kind of process (McFall, 2015). 
Comparing the modes of social delimitation between individuals in France and the United States, Michèle Lamont (1992) considers that the French establish anti-socio-economic boundaries: other distinction criteria are predominant and economic criteria are judged as vulgar and to be avoided at all cost. These representations are in line with French society's meritocratic vision of itself and French sociology has indeed described French society in this way. In Bourdieu's sociology, inequalities in economic capital have received little analysis as such: social differences are explained above all by the distribution of cultural, social, and symbolic capital. In a way, the effects of the differential distribution of income have not received much attention from either French society or French sociology.

Notwithstanding, significant changes have occurred over the past thirty years, particularly as a result of the economic crisis, the rise in unemployment, and a decline in the belief of meritocracy. The unequal quality of public services (hospitals, schools, administrative services, etc.) according to neighborhood wealth has become increasingly apparent. Purely monetary issues are present in political debates: the amount of aid given to the poor, the differences in salaries among employees, the salaries of politicians, and so on. It is not at all true to say that nobody talks about money in France - it is simply that these discussions concerning money seldom touch on the issue of financial tools and are not thematically structured around the idea of the financialization of daily life. There is no equivalent in France for the "Your Money" section in the New York Times, which explores questions about student loans, credit scores, investment choices, etc. on a daily basis. The major newspapers in France have economic and financial supplements that are principally devoted to wealth management, and are thus addressed to their richest readers. As such, the political effect of contemporary money management techniques is scarcely analyzed in either public or scientific debate. Does this signify that French people's daily life is not financialized?

In France, 99\% of households possess a bank account and the majority of the population has made use of banking services since the early 1970s, which is when the great movement that familiarized the population with the banking world took place. In the 1980s, banks were privatized, regulation was relaxed, facilitating the flow of credit, investment products proliferated, and a part of household savings was invested in the stock market. That said, the percentage of their savings that French households have invested in the stock market is small relative to other OECD countries; for example, $19.3 \%$ of households owned stocks in 2010 (down from $24.2 \%$ in 2004 - like in many other countries, the 2007 crisis drove off investors, who chose more secure 
products). The share of investors increases with each speculative bubble, then decreases after it bursts. Moreover, the majority of pensions in France operate on a pay-as-you-go system, and therefore, households do not possess many financial products for retirement savings (12\% did in 2010). French banks continue to buffer turbulence in the financial sector in a number of ways: with savings accounts, which is to say by way of small but guaranteed interest rates that do not threaten to diminish capital; with fixed-rate credits that cannot be altered over the duration of the loan, including for real estate loans; and by maintaining branch offices, which ensures that their business models continue to be based predominantly on face-to-face interactions.

Colin Crouch provides one way to describe household financialization with the term "privatised Keynesianism" (2009): it is no longer the state but rather households that indebt themselves to cope with increasing financial instability, decreasing wages, the retreat of the welfare state, and diminishing collective protections at the same time as an increase in the cost of living. This is not entirely the case in France: household indebtedness has certainly increased - reaching $86 \%$ of gross income in 2015 , whereas it was only $52 \%$ in 2000 (Banque de France) - but this increase has not taken on the proportions that it has in other countries. The French banking system also has the specificity of being exceptionally prudent. In particular, the way in which real estate loans are granted (by measuring the social and economic integration of borrowers in great depth) leads to the first deciles having very little access to credit relative to other countries. There is no "fringe banking" system in France due to the fact that interest rates are capped by the state.

Relative to insurance, the "risk shift" (Hacker, 2008) described in other developed countries is less noticeable in France because collective insurances for health, retirement, and unemployment have remained predominant. This is not to say that "risk shift" is not at work in France. Professional careers are more erratic and the recurrent collapse of financial bubbles leads a segment of savers to lose their money on the stock market. Though most French mortgage borrowers escaped the misfortunes that befell floating rate loan holders, some of them had taken out loans borrowed against the Swiss franc. Similarly, local governments found themselves deeply indebted due to increased interest rates. Nevertheless, private insurance remains less developed in France than elsewhere. While a very large segment of the population owns supplementary health insurance policies and pre-funded pension schemes, the core of French insurance remains collective; or, more exactly, France does not see itself as a country with private insurance, since mutual organizations are not seen as financial enterprises but rather as businesses belonging to the social economy. 
Another way to identify the consequences of the financialization of daily life is to show the inequalities of what Fourcade and Kieran (2013) call "life chances". While Georges Gloukoviezoff (2010) showed that access to financial products and skills in using them are indispensable to social life in France as elsewhere, there are no quantified measures that prove the connections between difficulty in accessing financial products and social success - partially because it is very difficult to obtain bank data in these areas. Additionally, this access to banking products has not affected individual subjectivity in France as can occur in the United States, for example, through the circulation of credit scores and credit reports in hiring processes (Kivat, 2014), in the access to housing, and even in romantic life (Silver-Greenberg 2012). Moreover, the access to higher education in France is much less contingent on the access to money than is the case elsewhere.

Nevertheless, France is not insulated from trends present in the rest of the world, and has experienced an acceleration of financial exchanges, changes in legislation, and upheavals in the organization of work. In his book on public debt in France, Benjamin Lemoine (2016) showed how the officials in charge of finance in the 1970s and 1980s deliberately chose to financialize the state's monetary resources, leading it to borrow on financial markets where it had previously benefited from a special circuit within the French economy.

Alvarez (2015) affirms that "France has experienced one of the most intense liberalization and financialization processes of any OECD country". He shows how the financialization of non-financial firms (Krippner, 2011) leads to a decrease in the bargaining power of employees. Isabelle Chambost (2016) describes the same phenomenon when speaking of "financial domination" within firms, which results in forms of social violence in the workplace. This financialization also produces a strong growth in wage inequality between the highest earning employees and the rest (Godechot, 2016). In her work on the wealth of the rich, Camille Herlin-Giret (2016) shows there has also been a quantitative and qualitative transformation in the management of private wealth, which is invested in increasingly complex ways in order maximize profits and minimize fiscal costs. These complex financial products concern the richest segment of the population; while the middle and working classes have certainly been able to purchase securities through their banks and by more direct avenues since the 1980 s, the most common savings products remain banking services, which is to say products with fixed interest rates, heavy state supervision, little exposure to risk, and limited yields.

Moreover, a growing segment of the population is finding itself at the margins of the labor market due to offshoring, layoffs, and the pursuit of 
productivity gains. As opposed to other countries, France is affected less by a proliferation of extremely precarious jobs than by massive unemployment, which marginalizes a growing part of the population. The vector by which finance most directly affects French households is that of work.

Should an analytic distinction be made between these two types of financialization? If the aim is to understand what kind of subjectivity these changes engender, the direct relationship with finance undoubtedly creates a more pronounced financial subjectivity. A person who loses his job because his company was bought out by a pension fund and decided to lay off workers to increase profits finds his life turned upside-down by the financialization of the economy, but he cannot be described as a "financial subject" of the kind described by Paul Langley (2008b) or Donncha Marron (2014).

It is easy to chart economic connections between the financialization of the economy and household finances: the practices of banks and companies, the concentration of wealth, and the immense profits made by a small segment of the population impact the impoverishment of certain social categories, resulting in lower living standards, difficulty or impossibility to repay credits, and a social vulnerability that affects health, children's academic success, and even life expectancy. Is "the financialization of daily life" simply a modern expression for "impoverishment"? When households find their monetary resources insufficient to meet their expenses, money issues begin to take up more space and it becomes necessary to implement more elaborate monetary technologies. This was the case during the monetary crises in Argentina (Luzzi, 2015) and elsewhere (Théret, 2008). Following this line of logic, should we consider that we are faced with a historical inversion of the several decades of Fordist and Keynesian regimes during which the financial stability of households was a major political goal (Crouch, 2009; Saillard and Boyer, 2010)? Households at the time had no need for loan sharks nor for credit from merchants - in a way, there was a "definancialization of daily life". The French case is particularly interesting: in the 1950s and 1960s, a series of legislative measures led nearly all personal money to be deposited in bank accounts and all credit to be obtained from strictly regulated financial institutions, putting an end to what was called "black credit" (Effosse, 2014) - credit not acquired from banks. As was the case in many other countries, the French had juggled (Villarreal, Guérin, and Kumar, 2015) several sources of money (Fontaine, 2008) until then, and, as Zola describes in L'Argent (2012 [1891]), they were able to participate in the world of high finance. Their financial savoir-faire suddenly deteriorated, becoming limited to an understanding of retail banking, which in France can be considered as a definancializing "from above", as a 
buffer between individuals and high finance, and "from below", by ending the juggling of multiple sources of money.

This situation has changed in two ways: firstly, the products offered by the banks are less protective. Many scandals have broken out over the past twenty years due to banks investing their clients' money in risky products without having sufficiently informed them. Secondly, the French vision of a non-financialized society, which is to say a society that is not organized around monetary wealth but rather around cultural and social wealth, has changed. This vision was mythical to a certain degree - indeed, there have always been monetary inequalities in France. Still, French society's dominant discourse about itself was a non-monetary one. This is no longer the case. There is a form of financialization taking place through the growing importance money takes in public debate: public money through the focus on the "problem" of public debt (Lemoine, 2016); private money through the debates on the salaries of civil servants and the proliferating publications and reports on the fact that "the poor pay more", as David Caplovitz put it (1963).

One of the ways to perceive these developments in the space occupied by personal money in society is to observe the public authorities' increasingly clear recognition of the issue of personal finance as a subject for political intervention.

\section{Indirect effects of financialization: the monetarization of social intervention}

France is experiencing a political upheaval regarding the monetary practices of individuals: there has been a major reform of the overindebtedness procedure in 2010, followed by adjustments in 2011, 2013, and 2014; the addition of "banking inclusion" as an objective in the multi-year plan to fight against poverty, established in 2013, which led to the creation of the Observatory of Banking Inclusion within the Banque de France in 2014; the introduction of a national financial education strategy (CCSF, 2015); and, in January 2016, the implementation of budget advice points - sites dedicated to the prevention of financial difficulties, whose main innovation consists in the early detection of financial difficulties through the networking of various actors that are able to notice budgetary problems (social housing providers, energy providers, telephone companies, banks, etc.).

As such, while it is difficult to establish a financialization of daily life in France in the sense of a qualitative transformation of the use of financial products by individuals, it is possible to affirm that the effects of the financialization of the economy, through the destabilization of work and the 
impoverishment of a percentage of employees, leads social policies to focus on the issue of household money management rather than on that of poverty. Indeed, while some of the policies cited above are connected with the fight against poverty, they are not limited to this purpose - on the contrary, they seek to distinguish themselves from it. What is important to the promoters of these policies is actually to show that money management and financial know-how have their own effects on an individual's level of wealth. On one hand, this line of reasoning can serve to justify a limitation of social transfers, framing the issue as teaching the poor to manage money rather than giving them ever more. This argument is not new, and the idea that the working class needs to be taught how to consume and how to save is as old as the social treatment of poverty. In the post-war period, the "definancialized" French society believed in security through the welfare state, and mostly abandoned budgeting education, considered obsolete and paternalistic. When the risks are re-individualized, the state and the social sector once more take up the question of household finance, but in a way that is necessarily different, as it is no longer the $19^{\text {th }}$ century: household money now passes through bank accounts; bills are paid electronically; and, more generally, keeping a home requires an almost administrative familiarity with actors as diverse as energy providers, telephone companies, landlords, insurers, tax authorities, and so on. A social worker's intervention with an individual very often involves an initial clarification of the different contracts and commitments subscribed to by the individual, who upon encountering financial difficulties may sometimes be overwhelmed by the written correspondence, various fees, and collection methods of different entities. Before being financialized, daily life is first bureaucratized. Social workers in France are experts in social rights, the procedures to obtain them, and the legal regulations concerning them; their intervention in households has long been considered that of an intermediary between social law and families.

One indirect effect of financialization is a change in outlook on the role of these intermediaries: their interventions are no longer expected to be limited to interactions between individuals and the social state, but must also take into account the fact that people's daily lives are embedded in interactions with the private sector, such as with banks. The perspectives on the way the state can supervise household finances are changing. The destabilization of work that is particularly connected to financialization and the pauperization engendered by mass unemployment are paradoxically treated as individual evils. The political and ideological balance of power leads the defense of poverty in the name of a classical humanism to founder. Poverty must be fought with the tools of 
empowerment, incentives, and accountability. While conditional cash transfers do not exist in France, public assistance is harshly criticized and both political authorities and street level bureaucrats constantly repeat that the beneficiaries of social services must themselves make efforts.

Historically, there are two main policies concerning the management of personal money: first, a personal credit policy that must encompass the sometimes barely compatible development of consumption and protection of borrowers (Chatriot, 2006; Trumbull, 2014); second, the procedure for handling overindebtedness (Salomon, 1995; Plot, 2011; Lacan, 2013), introduced in 1989. These two policies are the subject of constant reforms. Overindebtedness is handled by the Banque de France, which mediates with creditors in order to establish a repayment plan based on the borrower's "repayment capacity". If there is some debt remaining at the end of the plan, it may be forgiven. The reforms follow the changing profile of the overindebted: while the majority of these people belong to the lower middle class, with a job and thus access to credit, an increasing number is in "irreparably compromised" situations their income is too low to reimburse their debts, which for some are not due to credit but rather to debts accumulated in daily life, such as rent or bills. For this reason, a law was passed in 2003 to create a new procedure for debt cancellation, or civil bankruptcy, which had not existed previously.

Credit management policies oscillate between the desire to protect consumers against excessive indebtedness and to support consumption by facilitating access to ready cash (Effosse, 2014). One of the major tools used by these policies is the "usury rate" (maximum interest rate), the primary effect of which is to prevent the giving of credit when the risk is too great, as lenders cannot adjust the interest rate to the risk. The organization of the credit system, by both banks and regulators, is conceived for the salaried middle classes who take on debt in order to finance large purchases. Revolving credit and credit cards used for daily expenses are unanimously perceived as problematic tools, and some politicians have even suggested banning them.

\section{Budget advice points}

This quick scan of the main regulations concerning household money shows the importance of the definition of targeted categories. The conception of credit regulation differs according to whether its users are described as members of the autonomous and rational middle class or as members of the working class, considered more vulnerable and in need of protection from banks as well as from their own behavior. Since January 1st, 2014, French banks have been obligated to propose a specific offer to their "fragile clients", 
which has had the effect of establishing the means to detect and qualify this clientele. The latest tool, budget advice points, which are sites for individuals to receive advice and for mediation between individuals and creditors to take place, presents a very ambiguous situation.

This is one in a series of initiatives that bring creditors, social services, and charitable organizations closer together. A social space was constituted (Lazarus, 2013) following the introduction in 2005 of "social" micro-credits (Gloukoviezoff and Rebière, 2013) guaranteed by the state, lent by banks, and implemented by charitable organizations. These actors next convened on financial education initiatives. The budget advice points came up following these discussions. Proposed during a national conference for the fight against poverty (in 2013), they were abandoned, and then put back on the agenda, passing from the Ministry of Social Affairs to the Ministry of Economy, and finally being placed under the aegis of Social Affairs beginning in January 2016. It is not, as one project actor said, an "umpteenth tool for giving advice" but rather a project that seeks to be "modern"; it does not simply propose to offer individuals budgetary advice, but rather to act as an intermediary between individuals and their creditors with mediation tools such as debt recalculation, maturity schedules or even forgiveness of certain debts, and through advising tools that are presented as respectful of the autonomy of those experiencing financial difficulties and which are purely technical, with no moral stakes. These structures are still in an experimental stage, and what interests us here is less the details of how they work than to see them as one of the main tools of the transformations taking place.

They embody these transformations in two ways: firstly, because creditors are deeply involved in the project's implementation. It is the creditors that are financing the project (the state does not give money to associative structures that receive the "budget advice point" label), but their participation is not mandatory and are not submitted to standardizing rates by the state. As such, the creditors enter into agreements with various associations and can put an end to these agreements at any time if the services are not to their liking. The service they expect is to get debtors to reimburse what they owe at the lowest cost. The associations are thus in charge of studying the budgetary structures of the individuals sent to them so as to determine repayment plans. Here, we are dealing with a hybrid structure at the interface between traditional debt collection and budget guidance. This model did not arise by chance: it was developed over the course of several years by an association that describes itself as a participant in "social business", which is financed without public subsidies - that is to say, through training activities and services for creditors, 
particularly the management of clients experiencing financial difficulties. The highlighting of this model implicitly describes traditional social support as outdated because it is too bureaucratic in comparison to "social business", which is able to incorporate private sector constraints.

The budget advice points also embody a transformation in regards to the type of people concerned. All the actors involved in this policy are overjoyed by the fact that it is intended for the "middle classes". Indeed, the model is designed to work for people who have sufficient financial capacity to take on debt - thus, people with incomes. The term "middle class" is extremely vague and is often used simply as a synonym for "salaried", in opposition to the unemployed or people receiving only social benefits. The championing of this group suggests that the state had previously only taken care of the impoverished, undoubtedly in excess, and left behind deserving salaried workers.

This consensus in respect to the middle classes is a strong sign of the ideological change regarding social action: first, it is a recognition of the process of the weakening of those who were previously economically stable (Castel, 2013); second, it signals a utilitarian view on social action, whose intervention is meant to help deal with difficulties, not to accompany disadvantaged social categories over the long term. This arrangement is totally in line with the promotion of the "autonomy of those receiving assistance" (Duvoux, 2009) - intended to act on individual finances, it suggests that it is possible to disentangle the technical aspect of intervention from the social aspect, with the latter on the side of psychology, care, and good sense, and being considered relatively ineffective. As such, it deems that a household's finances can be reduced to a matter of accounting. More exactly, this oversimplification is only possible once the household has been labeled "middle class", which is to say capable of performing this balance between different aspects of daily life and the world of calculation. Belonging to the middle class thus means not only having sufficient income, but above all having adopted institutional modes of reasoning (be they credit institutions or governmental ones), which is to say knowing how to navigate the bureaucratization of daily life without help.

\section{Conclusion}

While the expression "financialization of daily life" is not perfectly suited to describe the French situation, the financialization of the economy is nevertheless transforming French ways of life and income stability as it does elsewhere, and it is from this angle that public authorities get involved. The most notable change is the "monetarization" of social intervention: in addition to helping individuals integrate into the bureaucracy of daily life, social 
workers are increasingly made to take account of the money management of these individuals and the monetary commitments they have contracted with lenders and other service providers. On this subject, Pascale Moulévrier (2014) speaks of "financialization of social action". She points out not only the fact that social workers offering micro-credits have to apply banking standards, but also that financial education is largely delegated to or organized in cooperation with banking structures (Mialet and Moulévrier, 2016). We consider the term "financialization" to be problematic here because it is not a question of financing actions through the banking world (or only to a limited extent, since most social action remains public or associative). Moreover, these programs primarily offer assistance in the management of basic banking products and contractual commitments with service providers - they are more about budgetary than financial education. This does not correspond to the definition of financialization that we set out, namely the bridging of individual budgets and the world of high finance.

It may seem surprising to suggest that social policies and, to an even greater degree, anti-poverty policies in France were not focused on money before recent years, as they consist precisely in organizing redistribution and thus in organizing major financial flows. The tasks of agents, however, were and largely remain centered on access to rights much more than on the control of users' monetary practices, even if control may be exercised through judicial measures (administrative supervision in particular) or through the intervention of social and family finance counselors, such as when an individual files documents for overindebtedness or risk of eviction. Budget advice points announce two crucial new developments: first, monetary practices are considered to be important, as they have a potentially negative impact on social situations, independent of an individual's resources; second, the very existence of this policy suggests that it is possible, by way of an as yet undefined intervention, to transform the practices of individuals.

Starting from the French case, we can thus conclude that the notion of financialization of daily life should not be used as a black box, but rather confronted with each local situation by including the organization of its social protection system, the history of its banking system, and the extent to which its labor market has been liberalized. If in France as elsewhere there is a chain of connections between household practices and the world of high finance, the organization of this chain implies many private and public actors, showing that the financial endangerment of daily life is not natural but rather the result of political choices. 


\section{References}

ALVAREZ, Ignacio. Financialization, non-financial. Corporations and income inequality: the case of France. Socio-economic Review, v. 13, n. 3, p. 449-475, 2015 $<10.1093 / \mathrm{ser} / \mathrm{mwv} 007>$.

ATKINSON, Anthony B.; PIKETTY, Thomas; SAEZ, Emmanuel. Top incomes in the long run of history. Journal of Economic Literature, v. 49, n. 1, p. 3-71, 2011 $<10.1257 /$ jel.49.1.3 $>$.

CAPLOVITZ, David. The poor pay more: consumer practices of low-income families. New York: Free Press, 1963.

CASTEL, Robert. L'insécurité sociale: qu'est-ce qu'être protégé? Paris: Seuil, 2013.

CCSF. La définition et la mise en œuvre d'une stratégie nationale d'éducation financière: report by the work group chaired by Emmanuel Constans, $2015<\mathrm{http}$ :/ www.ladocumentationfrancaise. fr/rapports-publics/154000141/index.shtml $>\left(1^{\text {st }}\right.$ Feb. 2017).

CHAMBOST, Isabelle. 2016. Les ressorts de la domination financière: le cas des LBO. In: Isabelle Chambost; Marc Lenglet; Yamina Tadjeddine (eds.). La fabrique de la finance. Lille: Presses du Septentrion, 2013.

CHATRIOT, Alain. Protéger le consommateur contre lui-même. Vingtième Siècle. Revue d'Histoire, v. 91, n. 3, p. 95-109, 2006 <10.3917/ving.091.109>.

CROUCH, Colin. 2009. Privatised keynesianism: an unacknowledged policy regime. The British Journal of Politics \& International Relations, v. 11, n. 3, p. 382-399, 2009 $<10.1111 /$ j.1467-856X.2009.00377.x>.

DUVOUX, Nicolas. L'autonomie des assistés: sociologie des politiques d'insertion. Paris: PUF, 2009.

EFFOSSE, Sabine. Le crédit à la consommation en France, 1947-1965: de la stigmatisation à la réglementation. Paris: CHEFF, 2014.

FONTAINE, Laurence. L'économie morale: pauvreté, crédit et confiance dans l'Europe préindustrielle. Paris: Gallimard, 2008.

FOURCADE, Marion; KIERAN, Healy. Classification situations: life-chances in the neoliberal era. Accounting, Organizations and Society, v. 38, n. 8, p. 559-572, 2013 $<10.1016 /$ j.aos.2013.11.002>.

GLOUKOVIEZOFF, Georges. L'exclusion bancaire: le lien social à l'épreuve de la rentabilité. Paris: PUF, 2010.

GLOUKOVIEZOFF, Georges; REBIERE, Nicolas. Microcrédit contre pauvreté: des prêts entre solidarité et marché. Paris: Editions de l'Atelier, 2013.

GODECHOT, Olivier. Wages, bonuses and appropriation of profit in the financial industry: the working rich. London: Routledge, 2016.

HACKER, Jacob S. The great risk shift: the new economic insecurity and the decline of the American dream. Oxford: Oxford University Press, 2008.

HERLIN-GIRET, Camille. Les mondes de la richesse: travailler et faire travailler le capital. Paris, 2016. Doctoral dissertation in Sociology, University Paris-Dauphine. 
HUSZ, Orsi. Comment les salariés suédois sont devenus des consommateurs de produits financiers: l'expérience des "comptes chèques salariaux" dans les années 1950 et 1960. Critique Internationale, v. 69, n. 4, p. 99-118, $2015<10.3917 /$ crii.069.0099>.

KRIPPNER, Greta R. Capitalizing on crisis. Harvard: Harvard University Press, 2011.

LACAN, Laure. L'argent des crédits: recours au crédit à la consommation, contraintes et pratiques de remboursements de petits fonctionnaires entre les années 1980 et les années 2000. Paris, 2013. Doctoral dissertation in Sociology, École Normale Supérieure.

LAMONT, Michèle. Money, morals, and manners: the culture of the French and the American upper-middle class. Chicago: University of Chicago Press, 1992.

LANGLEY, Paul. Sub-prime mortgage lending: a cultural economy. Economy and society, v. 37, n. 4, p. 469-494, 2008a <10.1080/03085140802357893>.

LANGLEY, Paul. The everyday life of global finance: saving and borrowing in America. Oxford: Oxford University Press, 2008b.

LAZARUS, Jeanne. L'epreuve de l'argent: banques, banquiers, clients. Paris: Calmann-Levy, 2012

LAZARUS, Jeanne. De l'aide à la responsabilisation: l'espace social de l'éducation financière en France. Genèses, v. 93, p. 76-97, 2013.

LAZARUS, Jeanne; LUZZI, Mariana. Les pratiques monétaires des ménages au prisme de la financiarisation. Critique Internationale, v. 69, n. 4, p. 9-19, 2015.

LEMOINE, Benjamin. L'ordre de la dette: enquête sur les infortunes de l'État et la prospérité du marché. Paris: La Découverte, 2016.

LUSARDI, Annamaria; MICHELL, Olivia S. Financial literacy and planning: implications for retirement wellbeing. National Bureau of Economic Research, n. 17078, $2011<$ http://www.nber.org/papers/w17078> (1 $1^{\text {st }}$ Feb. 2017).

LUZZI, Mariana. 2015. Socialisation économique et hiérarchies monétaires dans un contexte de crise: Argentine, 2001-2003. Critique Internationale, v. 69, n. 4, p. 21-37, $2015<10.3917 /$ crii.069.0021>.

MARRON, Donncha. "Informed, educated and more confident": financial capability and the problematization of personal finance consumption. Consumption Markets and Culture, v. 17, n. 5, p. 491-511, $2014<10.1080 / 10253866.2013 .849590>$.

MARTIN, Randy. Financialization of daily life. Philadelphia: Temple University Press, 2002.

MCFALL, Liz. Is digital disruption the end of health insurance? Some thoughts on the devising of risk. Economic Sociology. The European Electronic Newsletter, v. 17, n. 1, p. 32-42, 2015.

MIALET, Benoit; MOULEVRIER, Pascale. Éducation bancaire: l'émergence d'un espace financiarisé et privatisé d'encadrement des pauvres. Revue Tiers Monde, n. 225 , p. $155-178,2016<10.3917 / \mathrm{rtm} .225 .0155>$.

MOULEVRIER, Pascale. Le crédit donné aux pauvres. Sociétés Contemporaines, n. 92 v. 4, p. 89-106, $2014<10.3917 /$ soco.092.0089>. 
PLOT, Sébastien. Les enjeux d'une mise en risque: la construction du surendettement comme problème public (1989-2010). Paris, 2011. Doctoral dissertation in Political Sciences. Université Paris-Dauphine.

SAILLARD, Yves; BOYER, Robert. Théorie de la régulation, l'état des savoirs. Paris: La Découverte, 2010.

SALOMON, Danielle. La transformation du système bancaire français: l'exemple du segment du crédit à la consommation. Paris: IEP, 1995.

SILVER-GREENBERG, Jessica. Even cupid wants to know your credit score. The New York Times, 25 Dec. 2012.

THERET, Bruno. La monnaie dévoilée par ses crises. Paris: Éditions de l'École des Hautes Etudes en Sciences Sociales, 2008.

TRUMBULL, Gunnar. Consumer lending in France and America: credit and welfare. Cambridge: Cambridge University Press, 2014.

VILLARREAL, Magdalena; GUÉRIN, Isabelle; KUMAR, K. S. Santos. La richesse en jonglant: Saraswathi et Carola. Critique Internationale, v. 69, n. 4, p. 39-58, 2015 $<10.3917 /$ crii.069.0039>.

ZOLA, Emile. L'Argent (1891 edition). Paris: Hachette Groupe Livre, 2012.

ZUNZ, Olivier. Why the American century? Chicago: University of Chicago Press, 1998.

ZWAN VAN DER, Natascha. Making sense of financialization. Socio-economic Review, v. 12, n. 1, p. 99-129, $2014<10.1093 / \mathrm{ser} / \mathrm{mwt} 020>$. 